\title{
Chevroned Water Hyacinth Weevil Neochetina bruchi Hustache (Insecta: Coleoptera: Curculionidae) ${ }^{1}$
}

\author{
Eutychus Kariuki and Carey Minteer ${ }^{2}$
}

The Featured Creatures collection provides in-depth profiles of insects, nematodes, arachnids, and other organisms relevant to Florida. These profiles are intended for the use of interested laypersons with some knowledge of biology as well as academic audiences.

\section{Introduction}

Neochetina bruchi Hustache is commonly referred to as the chevroned water hyacinth weevil and is a weed biological control agent used to manage water hyacinth, Pontederia crassipes Mart. [formerly Eichhornia crassipes (Mart.) Solms (Pellegrini et al. 2018)], in more than 30 countries (Winston et al. 2014). Imported from Argentina, the insect was first introduced into the United States in Florida in 1974 and later released in Louisiana in 1974 (Manning 1979), Texas in 1980, and California from 1982 to 1983 (Winston et al. 2014). Chevroned water hyacinth weevils currently occur throughout the Gulf Coast States (Winston et al. 2014). The target weed of Neochetina bruchi, water hyacinth, is an invasive aquatic plant in the United States and is included on Florida's list of prohibited aquatic plants.

The chevroned water hyacinth weevil is among four species of insect biological control agents that have been introduced into the United States to manage water hyacinth. The other three species include a mottled water hyacinth weevil, Neochetina eichhorniae Warner; a moth, Niphograpta albiguttalis; and a planthopper, Megamelus scutellaris, which were introduced into the United States in 1972, 1977, and 2010, respectively (Tipping et al. 2014, Cuda and Frank 2019).

Although larvae and pupae of chevroned water hyacinth weevil and mottled water hyacinth weevil are similar in appearance and behavior and can be difficult to differentiate by casual observation (Deloach and Cordo 1976), adult stages of the two species of water hyacinth weevils can be distinguished relatively easily based on the color patterns on their elytra (hardened forewings) (see below).

\section{Description}

\section{Adults}

The adults of chevroned water hyacinth weevil are 3.5 to $4.5 \mathrm{~mm}$ (males) and 4.1 to $5.0 \mathrm{~mm}$ (females) in length (Deloach 1975). They are covered with dense brown and tan scales, which often form a distinctive crescent-shaped band (chevron) on the elytra (forewings) (Figure 1). Elytra are wider than the prothorax, and the ventral plate of the prothorax (prosternum) has a strong carina (an elevated ridge or keel). Antennae, tarsi, and apex of tibiae (Figure 1) are reddish brown (O’Brien 1976). Points of articulation and parts of the insect's underside (venter) are covered by yellowish hydrofuge (water-repellant) scales (O’Brien 1976).

1. This document is EENY-741, one of a series of the Entomology and Nematology Department, UF/IFAS Extension. Original publication date June 2020. Visit the EDIS website at https://edis.ifas.ufl.edu for the currently supported version of this publication. This document is also available on the Featured Creatures website at http://entomology.ifas.ufl.edu/creatures.

2. Eutychus Kariuki, post doctoral associate; and Carey Minteer, assistant professor; UF/IFAS Indian River Research and Education Center, Fort Pierce, FL 34945.

The Institute of Food and Agricultural Sciences (IFAS) is an Equal Opportunity Institution authorized to provide research, educational information and other services

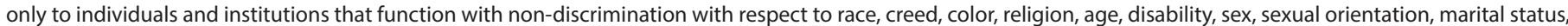

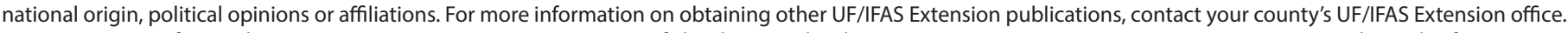
U.S. Department of Agriculture, UF/IFAS Extension Service, University of Florida, IFAS, Florida A \& M University Cooperative Extension Program, and Boards of County Commissioners Cooperating. Nick T. Place, dean for UF/IFAS Extension. 


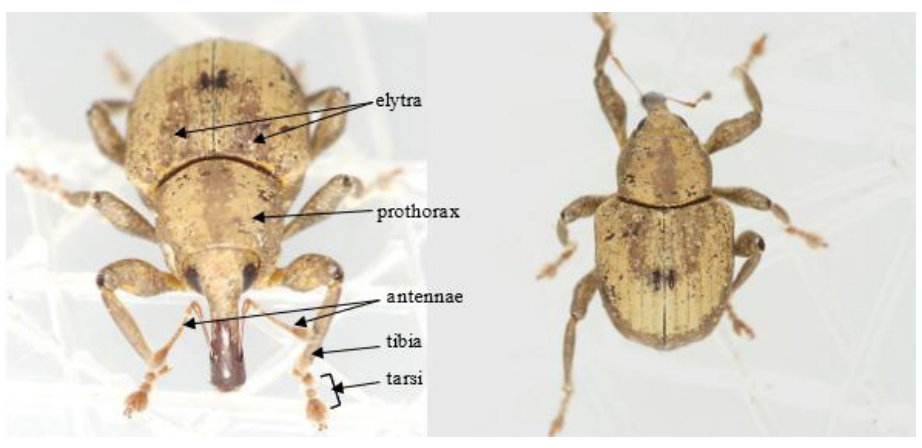

Figure 1. Adult of chevroned water hyacinth weevil, Neochetina bruchi Hustache.

Credits: J. Ott, https://bugguide.net/node/view/292142/bgimage

\section{Eggs}

The eggs measure about $0.82 \mathrm{~mm}$ long by $0.6 \mathrm{~mm}$ wide, appear whitish and ovoid, and have rigid chorions (outer shell of an insect's egg) (DeLoach 1975, Deloach and Cordo 1976).

\section{Larvae}

The larvae are white with a brown head capsule (Figure 2). The head capsule of the first instar measures $0.3 \mathrm{~mm}$, second instar $0.5 \mathrm{~mm}$, and third instar $0.7 \mathrm{~mm}$ (Deloach and Cordo 1976).

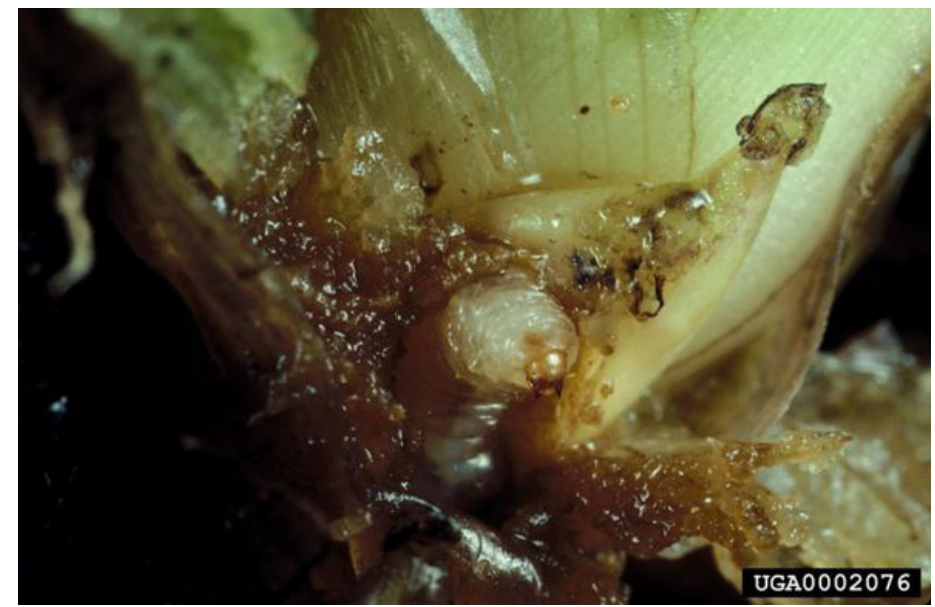

Figure 2. Late-stage larva of Neochetina sp. feeding at the base of leaf petiole of water hyacinth, Pontederia crassipes Mart.

Credits: Willey Durden, USDA Agricultural Research Service, Bugwood. org

\section{Pupae}

The pupae are individually enclosed in light brown cocoons that appear chitinous. Deloach and Cordo (1976) reported that the immatures of chevroned water hyacinth weevil and mottled water hyacinth weevil have similar morphological characteristics and are difficult to distinguish by casual observation.

\section{Distribution}

Chevroned water hyacinth weevil has been introduced and established in more than 30 countries worldwide (Figure 3).

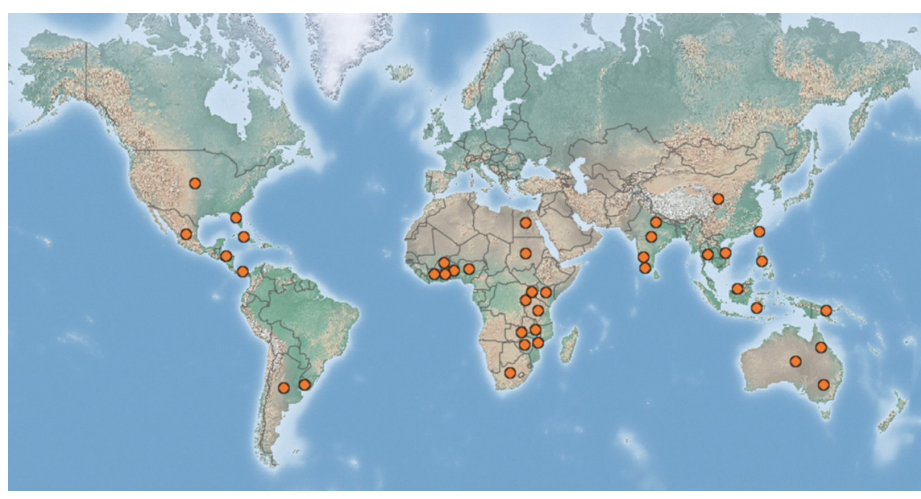

Figure 3. Map showing global distribution of chevroned water hyacinth weevil, Neochetina bruchi Hustache. Orange dots represent areas with reported occurrence of chevroned water hyacinth weevil. Credits: Center for Agriculture and Bioscience International. (Available online at: https://www.cabi.org/isc/datasheet/35785\#toDistributionM aps. Accessed 16 April 2020)

\section{Life Cycle and Biology}

Females of chevroned water hyacinth weevil deposit about 1 to 16 eggs per oviposition spot in the second or third layer of aerenchyma cells (spongy tissue consisting of an interconnected network of intercellular air spaces) of the leaf petioles, mostly in the older bulbous leaves (Deloach and Cordo 1976). Females begin laying eggs within the first three days after emerging from pupal stage (adult eclosion) and successfully lay eggs at temperatures ranging from $10^{\circ} \mathrm{C}$ to $30^{\circ} \mathrm{C}$ (Deloach and Cordo 1976).

Females lay the highest number of eggs per day within their first week after adult emergence and decline drastically thereafter (Deloach and Cordo 1976). For example, a laboratory study (Cordo and Deloach 1976) reported females of chevroned water hyacinth weevil deposited an average of 5 eggs per day within their first week after adult emergence before slowing down to an average of 1.5 eggs per day. The same study reported the oviposition and feeding rates of the insect peaked at about $30^{\circ} \mathrm{C}$, and females lived for an average of $47 \pm 21$ days.

A laboratory experiment performed at $25^{\circ} \mathrm{C}$ revealed the eggs of chevroned water hyacinth weevil incubate for about 7.6 days (Deloach and Cordo 1976). Neonates (newly hatched larvae) tunnel the petioles of water hyacinth, where they feed on the internal tissues, creating feeding pockets. Developing larvae usually occur singly within a feeding pocket and complete development through three instars (developmental stages) in about 32 days (Deloach 
and Cordo 1976). The mature larvae exit the petioles and pupate underwater attached to roots of water hyacinth. The prepupae stage lasts seven days, and pupal development lasts 23 days. In total, the insect completes development from egg to adult stage in about 70 days (Deloach and Cordo 1976).

\section{Host}

The primary host for chevroned water hyacinth weevil is water hyacinth (Figure 4) (Perkins and Maddox 1976). Negligible weevil damage has been reported in anchored water hyacinth, Pontederia azurea Sw. [formerly Eichhornia azurea (Sw.) Kunth (Pellegrini et al. 2018)], and Pickerelweed, Pontederia cordata L., when the two species grow near weevil-infested water hyacinth plants (Perkins and Maddox 1976). Anchored water hyacinth is included on the federal noxious weed list and Florida's list of prohibited aquatic plants. Pickerelweed lacks the underwater roots required by the weevil to complete pupal development and, therefore, isolated pickerelweed stands can not support a complete life cycle of the weevil (Perkins and Maddox 1976).

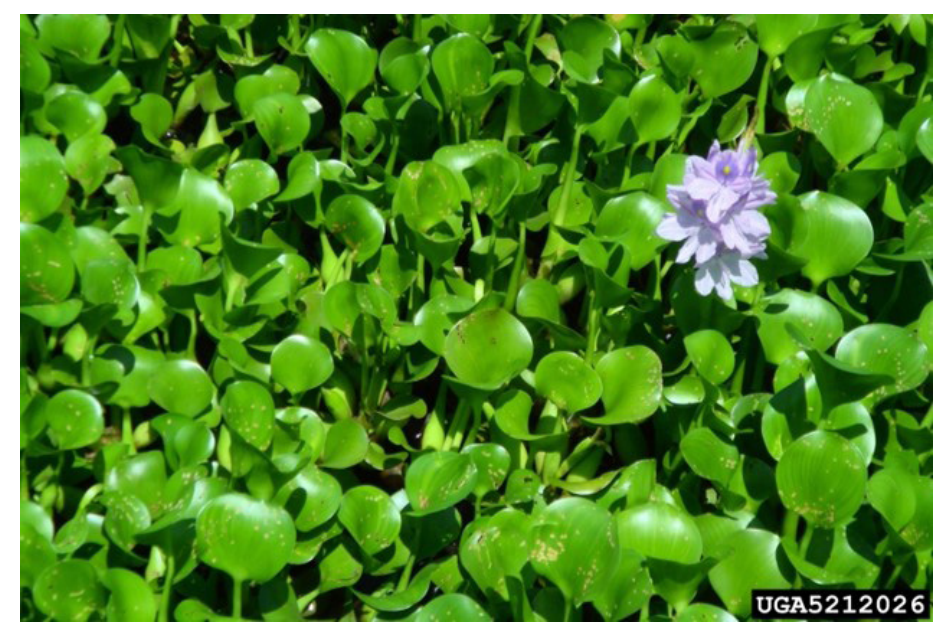

Figure 4. Water hyacinth, Pontederia crassipes Mart., plants. Credits: Katherine Parys, USDA-ARS, Bugwood.org

\section{Damage}

Larvae of chevroned water hyacinth weevil are internal feeders and cause damage to water hyacinth by mining inside the petiole of a water hyacinth leaf. The margins of infested leaves develop yellow streaks and dryness (Figure $5)$.

Adults of chevroned water hyacinth weevil are external leaf feeders; they feed on the epidermal layer and deep into the subepidermal layer, creating feeding scars (Figure 6) with area averaging $4.5 \mathrm{~mm}^{2}$ (Deloach and Cordo 1976). Adults mostly feed on the upper surface rather than the lower

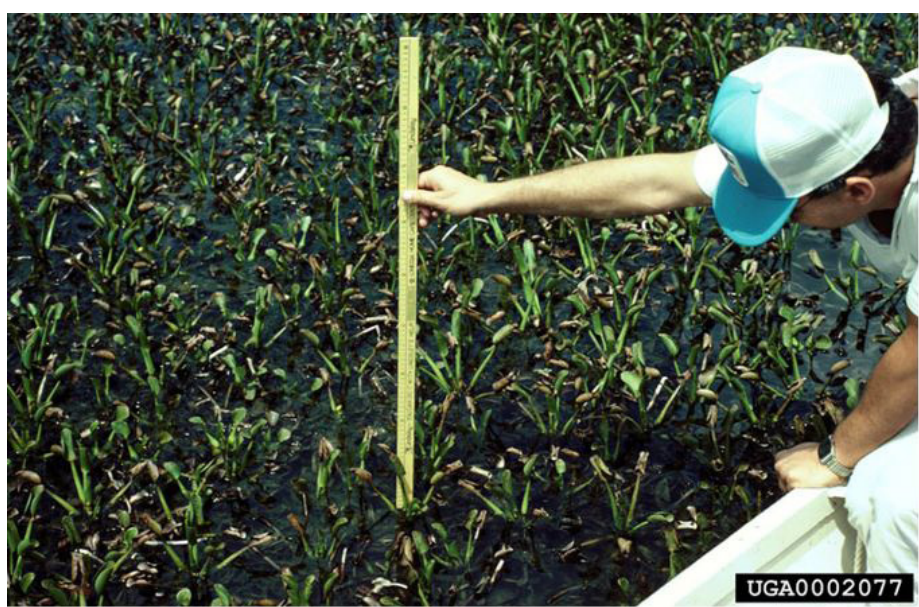

Figure 5. Water hyacinth, Pontederia crassipes Mart., plants damaged by Neochetina sp. exhibit stunted growth.

Credits: Willey Durden, USDA Agricultural Research Service, Bugwood. org

surface of the leaf, and each cumulatively consumes up to $75 \mathrm{~mm}^{2}$ of leaf surface area per day (Deloach and Cordo 1976, Bashir et al. 1984). Females prefer feeding on older, bulbous leaves and consume three times as much leaf tissue as males (Deloach and Cordo 1976). A casual observation may not reveal any difference between the feeding scars caused by adults of chevroned water hyacinth weevil and mottled water hyacinth weevil (Deloach and Cordo 1976). However, microscopic comparisons of leaf damage by the two weevil species revealed adults of mottled water hyacinth weevil barely consumed the subepidermal layer and caused $20 \%$ more damage in terms of leaf surface area compared to chevroned water hyacinth weevil (Deloach and Cordo 1976, Bashir et al. 1984).

Plants damaged by chevroned water hyacinth weevil produce less biomass and flowers, and, in cases where a plant is heavily damaged, the plant may eventually lose buoyancy and sink to the bottom of the water body (Moran 2005, Tipping et al. 2014, Winston et al. 2014). Additionally, feeding scars caused by the Neochetina adults have been reported to predispose water hyacinth to fungal infection (Moran 2005). Evidence from a field study suggested chevroned water hyacinth weevil disperses from release sites passively through downstream movement of infested plants or actively through adult flight (Akers et al. 2017).

\section{Importance as a Biological Control Agent}

Chevroned water hyacinth weevil is a valuable tool in the management of water hyacinth in several countries (Winston et al. 2014). Chevroned water hyacinth weevil and mottled water hyacinth weevil cause similar damage 


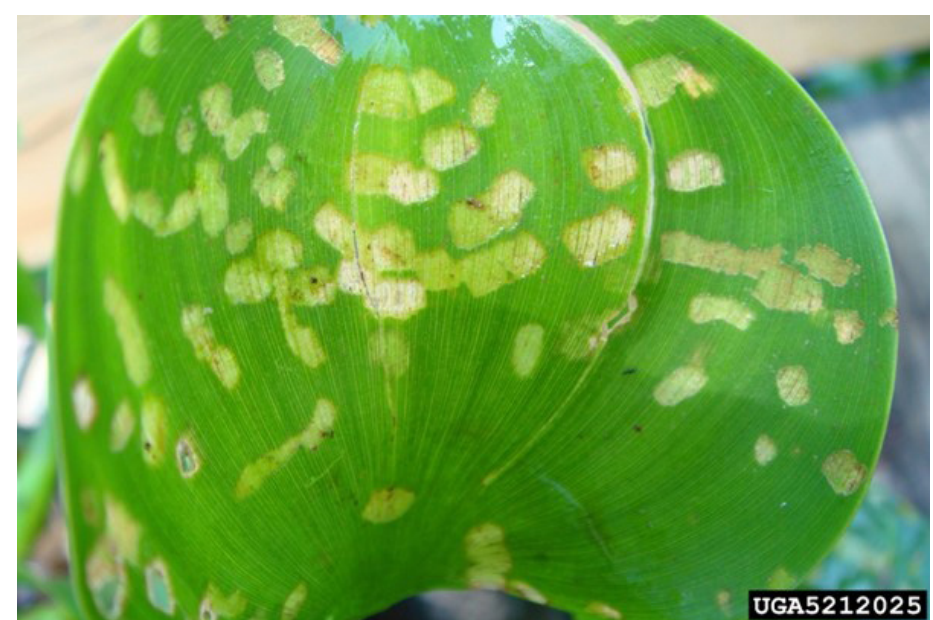

Figure 6. Typical feeding damage caused by adults of Neochetina species on a water hyacinth, Pontederia crassipes Mart., leaf. Credits: Katherine Parys, USDA-ARS, Bugwood.org

patterns on water hyacinth plants, so it is difficult to directly measure the impact of each species in regions where the two water hyacinth weevil species occur together. Overall, it is estimated that the introduction of the two water hyacinth weevil species reduced water hyacinth abundance in Gulf Coast States by 33\% (Winston et al. 2014).

The relative abundance of the two water hyacinth weevil species varies by region. In Florida, biological control agents released for water hyacinth control is dominated by mottled water hyacinth weevil and cumulatively reduces the biomass of water hyacinth by about $58 \%$ and production of flowers by $97 \%$ (Tipping et al. 2014). Chevroned water hyacinth weevil constituted a lesser proportion of total Neochetina adults found on water hyacinth plants in Florida, with a reported proportion ranging from less than 1\% (Tipping et al. 2014) to 30\% (Center and Dray 1992). In contrast to Florida, field surveys in Sacramento-San Joaquin River Delta in California showed chevroned water hyacinth weevil was the dominant biological control agent and accounted for more than $96 \%$ of the total Neochetina adults found on water hyacinth plants (Akers et al. 2017, Hopper et al. 2017). The number of chevroned water hyacinth weevil adults per plant ranged from 0 to 10.9 in 2002 (Akers et al. 2017) and 0.31 to 6.31 in 2017 (Hopper et al. 2017). In Louisiana, biological control agents that included chevroned water hyacinth weevil reduced the growth rate of water hyacinth population by $84 \%$ between 1976 and 2013 (Manning 1979, Nesslage and Wainger 2016). In Argentina, a study conducted in a reservoir of Dique Los Sauces revealed chevroned water hyacinth weevil solely reduced the surface coverage of water hyacinth from an original level of $50 \%$ to a range of $4 \%$ to $8 \%$ in two years (Deloach and Cordo 1983).
Despite the documented evidence of the water hyacinth weevils suppressing the performance of water hyacinth, there are concerns in certain regions that the surface coverage of the plant appears unchanged because floating mats of aquatic plants are subject to compression and dispersion (Tipping et al. 2014). As a result, without detailed assessment, the presence of surface mats may create an incorrect perception to aquatic weed managers that water hyacinth weevils are ineffective, as well as disincentivize potential shifts in herbicide use patterns and integration of the contribution of insect biological control agents in water hyacinth management plans (Tipping et al. 2014). Studies in Florida reported the presence of weevils can reduce herbicide usage by $50 \%$ without loss in efficacy, demonstrating the potential benefits of incorporating chevroned water hyacinth weevil and mottled water hyacinth weevil into integrated pest management plans for water hyacinth (Gettys et al. 2014, Tipping et al. 2017).

Like many other insect species, the performance of chevroned water hyacinth weevil is prone to influence by factors such as host plant quality, ambient temperature, and pressure from natural enemies (Crawley 1989, Moran 2005). Laboratory studies have reported that compared to mottled water hyacinth weevil, chevroned water hyacinth weevil performs better on host plants growing in nutrientrich environments (Heard and Winterton 2000) and have better survival in colder environments (Deloach and Cordo 1976). A microsporidian disease caused by Nosema sp. was discovered attacking Neochetina spp. in Florida and reported to decrease adult survival rate by $30 \%$ and female fecundity by $62 \%$ (Center and Rebelo 2001, Goettel and Inglis 2006). An earlier study in the native range of the insect demonstrated chevroned water hyacinth weevil can be infected by microsporidiosis, attacked by nematodes (Metaparasitylenchus sp.), and infested by mites (Histiostoma n. sp. and Lasioseius sp.) (Deloach and Cordo 1982). As a result, it is generally recommended to ensure insect biological control agents are free of pathogens and parasites prior to releasing the insect agents into new environments.

\section{Monitoring and Management}

Samples of water hyacinth plants can be visually searched for the presence of adults and larvae of chevroned water hyacinth weevil, feeding scars on the leaves, and feeding pockets within leaf petioles (Tipping et al. 2014, Hopper et al. 2017). Alternatively, samples of water hyacinth plants can be fragmented and placed in Berlese funnels to extract any larvae or adults of chevroned water hyacinth weevil (Tipping et al. 2014, Hopper et al. 2017). 


\section{Selected References}

Akers RP, Bergmann RW, Pitcairn MJ. 2017. Biological control of water hyacinth in California's Sacramento-San Joaquin River Delta: observations on establishment and spread. Biocontrol Science and Technology 27: 755-768. https://doi.org/10.1080/09583157.2017.1342220

Bashir MO, El Abjar ZE, Irving NS. 1984. Observations on the effect of the weevils Neochetina eichhorniae Warner and Neochetina bruchi Hustache on the growth of water hyacinth. Hydrobiologia 110: 95-98. https://doi.org/10.1007/ BF00025780

Center TD, Dray Jr FA. 1992. Associations between water hyacinth weevils (Neochetina eichhorniae and N. bruchi) and phenological stages of Eichhornia crassipes in southern Florida. Florida Entomologist 75: 196-211. https://doi. org/10.2307/3495622

Center TD, Rebelo MT. 2001. Microsporidia and Neochetina. Water Hyacinth News 4: 5-7.

Crawley MJ. 1989. The successes and failures of weed biocontrol using insects. Biocontrol News and Information 10: 213-223.

Cuda JP, Frank JH. 2009. Florida's Established Arthropod Weed Biological Control Agents and Their Targets. ENY-853. Gainesville: University of Florida Institute of Food and Agricultural Sciences. https://edis.ifas.ufl.edu/in779 (Accessed 5 June 2020)

Deloach CJ. 1975. Identification and biological notes on the species of Neochetina that attack Pontederiaceae in Argentina (Coleoptera: Curculionidae: Bagoini). Coleopterists Bulletin 29: 257-285.

Deloach CJ, Cordo HA. 1976. Life cycle and biology of Neochetina bruchi, a weevil attacking water hyacinth in Argentina, with notes on N. eichhorniae. Annals of the Entomological Society of America 69: 643-652. https://doi. org/10.1093/aesa/69.4.643

Deloach CJ, Cordo HA. 1982. Natural enemies of Neochetina bruchi and N. eichhorniae, two weevils from waterhyacinth in Argentina. Annals of the Entomological Society of America 75: 115-118. https://doi.org/10.1093/ aesa/75.2.115

Deloach CJ, Cordo HA. 1983. Control of waterhyacinth by Neochetina bruchi (Coleoptera: Curculionidae: Bagoini) in
Argentina. Environmental Entomology 12: 19-23. https:// doi.org/10.1093/ee/12.1.19

Gettys LA, Tipping PW, Della Torre III CJ, Sardes SN, Thayer KM. 2014. Can herbicide usage be reduced by practicing IPM for waterhyacinth (Eichhornia crassipes) control? Proceedings of the Florida State Horticultural Society 127: 213-217.

Goettel MS, Inglis GD. 2006. Methods for assessment of contaminants of invertebrate biological control agents and associated risks, pp 145-165. In F. Bigler, D. Babendreier, and U. Kuhlmann (eds.), Environmental Impact of Invertebrates for Biological Control of Arthropods. CABI International, Wallingford, UK. https://doi. org/10.1079/9780851990583.0145

Heard TA, Winterton SL. 2000. Interactions between nutrient status and weevil herbivory in the biological control of water hyacinth. Journal of Applied Ecology 37: 117-127. https://doi.org/10.1046/j.1365-2664.2000.00480.x

Hopper JV, Pratt PD, McCue KF, Pitcairn MJ, Moran PJ, Madsen JD. 2017. Spatial and temporal variation of biological control agents associated with Eichhornia crassipes in the Sacramento-San Joaquin River Delta, California. Biological Control 111: 13-22. https://doi.org/10.1016/j. biocontrol.2017.05.005

Manning JH. 1979. Establishment of waterhyacinth weevil populations in Louisiana. Journal of Aquatic Plant Management 17: 39-41.

Moran PJ. 2005. Leaf scarring by the weevils Neochetina eichhorniae and N. bruchi enhances infection by the fungus Cercospora piaropi on waterhyacinth, Eichhornia crassipes. BioControl 50: 511-524. https://doi.org/10.1007/ s10526-004-4254-y

Nesslage GM, Wainger LA, Harms NE, Cofrancesco AF. 2016. Quantifying the population response of invasive water hyacinth, Eichhornia crassipes, to biological control and winter weather in Louisiana, USA. Biological Invasions 18: 2107-2115. https://doi.org/10.1007/s10530-016-1155-9

O'Brien CW. 1976. A taxonomic revision of the New World subaquatic genus Neochetina (Coleoptera: Curculionidae: Bagoini). Annals of the Entomological Society of America 69: 165-174. https://doi.org/10.1093/aesa/69.2.165

Pellegrini MOO, Horn CN, Almeida RF. 2018. Total evidence phylogeny of Pontederiaceae (Commelinales) 
sheds light on the necessity of its recircumscription and synopsis of Pontederia L. PhytoKeys 83: 25-83. https://doi. org/10.3897/phytokeys.108.27652

Perkins BD, Maddox DM. 1976. Host specificity of Neochetina bruchi Hustache (Coleoptera, Curculionidae), a biological control agent for water hyacinth. Journal of Aquatic Plant Management 14: 59-64.

Tipping PW, Martin MR, Pokorny EN, Nimmo KR, Fitzgerald DL, Dray FA, Center TD. 2014. Current levels of suppression of water hyacinth in Florida USA by classical biological control agents. Biological Control 71: 65-69. https://doi.org/10.1016/j.biocontrol.2014.01.008

Tipping PW, Gettys LA, Minteer CR, Foley JR, Sardes JR. 2017. Herbivory by biological control agents improves herbicidal control of waterhyacinth (Eichhornia crassipes). Invasive Plant Science and Management 10: 271-276. https://doi.org/10.1017/inp.2017.30

Winston RL, Schwarzländer M, Hinz HL, Day MD, Cock MJW, Julien MH. 2014. Biological Control of Weeds: A World Catalogue of Agents and Their Target Seeds, 5th ed. FHTET-2014-04. USDA Forest Service Publication, Morgantown, WV. 838 pp 